\title{
VIDAS EXPOSTAS NA REDE: UMA ANÁLISE SOBRE DIREITO AO ESQUECIMENTO, REDES SOCIAIS E JORNALISMO DIGITAL
}

DOI: $10.48075 /$ RI.V22I2.24959

Silvia Campos Paulino ${ }^{1}$

Daniele Ribeiro Fortuna ${ }^{2}$

Marcio Luiz Corrêa Vilaça ${ }^{3}$

RESUMO: O direito ao esquecimento, incialmente evocado na seara de fatos criminosos, ganha novos contornos com o avanço da internet e a propagação de informações, bem como com a relativização do direito à privacidade nas redes sociais, passando a ser instrumento na proteção aos direitos da personalidade no ciberespaço prelecionado por Lévy (2009[1999]). Com a replicabilidade inerente às redes sociais e aos jornais digitais, o avanço das informações tornou-se mais célere, levando os Tribunais brasileiros a utilizar do direito ao esquecimento digital para sopesar os princípios de acesso à informação e os direitos inerentes a personalidade. O presente artigo busca analisar brevemente este contexto, através de apanhado bibliográfico e jurisprudencial, e o posicionamento do Supremo Tribunal de Justiça no recurso especial no 1.660.168 - RJ julgado em 2018 que consagrou tal vertente do direito ao esquecimento no Brasil no que concerne o jornalismo digital. A metodologia do estudo é qualitativa, realizada por meio de pesquisa teórica e na análise documental, incluindo casos jurídicos.

Palavras-chave: Direito ao esquecimento. Redes sociais. Jornalismo digital.

\section{LIVES EXPOSED ON THE NETWORK: AN ANALYSIS ON THE RIGHT TO FORGETTING, SOCIAL NETWORKS AND DIGITAL JOURNALISM}

ABSTRACT: The right to be forgotten, initially evoked in the area of criminal acts, has gained new contours with the advancement of the internet and the propagation of information, as well as with the relativization of the right to privacy in social networks, becoming an instrument in the protection of the rights of the personality in the cyberspace preached by Lévy (2009[1999]). With the replicability inherent in social networks and digital newspapers, the advancement of information has become faster, leading Brazilian Courts to use the right to digital forgetting to weigh the principles of access to information and the rights inherent in personality. This article seeks to briefly analyze this context, through bibliographic and case law, and the position of the Supreme Court of Justice in the special appeal in 1,660,168-RJ judged in 2018, which enshrined this aspect of the right to oblivion in Brazil in what concerns the digital journalism. The

\footnotetext{
${ }^{1}$ Mestranda do Programa de Pós-graduação em Humanidades, Culturas e Artes (Unigranrio)

${ }^{2}$ Docente do Programa de Pós-Graduação em Humanidades, Culturas e Artes (Unigranrio), Jovem Cientista do Nosso Estado (FAPERJ)

${ }^{3}$ Docente do Programa de Pós-Graduação em Humanidades, Culturas e Artes (UNIGRANRIO), Jovem Cientista do Nosso Estado (FAPERJ)
} 
methodology of this study is qualitative, carried out through theoretical research and document analysis, including legal cases.

Key words: Right Personality law. Social networks. Digital journalism.

\section{INTRODUÇÃO}

O advento do ciberespaço, terminologia adotada por Pierre Lévy (2009), modificou as interações sociais do final do século XX, influenciando indelevelmente o século XXI, indo ao encontro da fluidez e da volatilidade da modernidade líquida vislumbrada por Bauman (2001). Os impactos e as implicações da cibercultura podem ser facilmente reconhecidos nas mais diversas práticas sociais e em campos acadêmicos e profissionais. Afinal, ela influencia as possibilidades e formas de interação, comunicação, consumo e aprendizagem. Este fato pode ser evidenciado no interesse que as temáticas relacionadas à cibercultura têm despertado em estudiosos dos mais diversos campos, como Comunicação, Direito etc.

A internet constituiu-se numa verdadeira galáxia, conforme as discussões de Castells (2003), visto as inúmeras interações existentes nessa nova conjuntura. Além da modificação da dinâmica social de interação, promove uma superexposição do indivíduo, uma espetacularização da vida cotidiana, na qual, segundo Debord (1997), o que era vivido diretamente tornou-se uma representação. Tais condições ensejam uma mitigação do direito à privacidade e aos direitos da personalidade. Tal prospecção da privacidade, dos dados e informações pessoais no ciberespaço é, sem dúvidas, alavancada pela replicabidade e permanência, conforme dispõe Recuero (2009), características próprias das redes sociais. Este fenômeno foi potencializado com as intensas mudanças nas formas de interação e participação na internet, que geralmente são características e efeitos oriundos da web 2.0, que marcou, no início dos anos 2000, uma significativa mudança nas formas de interação, comunicação e publicação de conteúdos na internet.

A internet também trouxe diversas modificações para o jornalismo. Segundo Daniela Bertochi (2016), no que diz respeito aos critérios de noticiabilidade no contexto comunicacional digital, a mediação (gatekeeping) ${ }^{4}$ pode desaparecer. Isso porque ciberleitores são capazes de decidir o que é notícia e como consumi-la.

Além disso, se antes, no jornalismo impresso, a notícia tinha um sentido mais efêmero, já que, o jornal, depois de algum tempo, estaria disponível somente em arquivos específicos, agora, ela se

\footnotetext{
${ }^{4}$ Grifo de Bertocchi
} 
tornou perene. Ao ser compartilhada na rede, dificilmente, uma informação poderá ser apagada, ainda que o veículo deixe de ser produzido.

Neste cenário, insurge a inquietação diante da tensão gerada entre direitos igualmente relevantes que são colocados em xeque, quais sejam: o direito à informação e os direitos da personalidade; tornando premente a discursão do que se convencionou doutrinariamente chamar de direito ao esquecimento digital. O direito ao esquecimento digital teve sua terminologia, the right to beforgotten, alcunhada pelo professor de governança na internet de Oxford Viktor MayerSchönberger em 2007, a fim de delimitar parâmetros de ponderação entre os direitos de personalidade e os direitos ao acesso à informação no ciberespaço.

Recentemente, em 2016, foi levado ao Superior Tribunal Brasileiro (STF), através de ação originária do Tribunal de Justiça do Rio de Janeiro (TJRJ), o debate acerca do direito ao esquecimento digital através do Recurso Extraordinário (RE) 1010606, sob relatoria do Ministro Dias Toffoli. O recurso, ainda pendente de julgamento, tem entre suas partes e amiccius curie ${ }^{5}$ os dois maiores buscadores da internet, Yahoo e Google, demonstrando a pertinência da presente discussão para a sociedade na atualidade.

A proposta deste artigo é discorrer acerca do direito ao esquecimento digital, destacando a consagração do tema pelo Superior Tribunal de Justiça (STJ) através do julgamento do recurso especial (Resp) número 1.660.168 - RJ em 2018, a fim de demonstrar como a relevância das informações expostas no ciberespaço, em especial nas redes sociais e nos jornais digitais, podem macular os direitos da personalidade, refletindo assim a influência do virtual sobre o real. A metodologia empregada no trabalho é qualitativa, realizada por meio de pesquisa teórica e na análise documental, recorrendo em alguns momentos a casos jurídicos (jurisprudência colacionada em especial do STJ) para exemplificação e discussão da temática central do trabalho: o direito ao esquecimento.

\section{CIBERESPAÇO, REDES SOCIAIS E BASES DE DADOS}

Pierre Lévy (1999) foi um dos pioneiros a se dedicar a não só observar a interferência da internet no meio social, mas também a nominar tal fenômeno, relacionando-o aos estudos da

\footnotetext{
5 O termo com origem do latim em tradução direta significa "amigo da corte" ou "amigo do tribunal "e é utilizado para designar pessoa ou entidade estranha a demanda que auxilia o tribunal de forma voluntária ou provocada conforme a pertinência temática fornecendo esclarecimentos ou informações essenciais à resolução da lide.
} 
cultura, alcunhando-o de cibercultura. Segundo Lévy (1999, p. 17), a cibercultura é "o conjunto de técnicas (materiais e intelectuais), de práticas, de atitudes, de modos de pensamento e de valores que se desenvolvem juntamente com o crescimento do ciberespaço". De acordo com o autor (LÉVY, 1999, p. 17), “o termo ciberespaço especifica não apenas a infraestrutura material da comunicação digital, mas também o universo oceânico de informação que ela abriga, assim como os seres humanos que navegam e alimentam esse universo". Dentro do contexto da cibercultura, observam-se novas formas de interações sociais e de comunicação, como a autocomunicação de massa destacada por Castells (2015) e Santaella (2003), na qual o elemento crucial é a produção difusa dos conteúdos consumidos. Nesse sentido, afasta-se o caráter passivo do receptor, que pode tornar-se produtor de conteúdo, visto a possibilidade propiciada pela internet. Castells (2015) destaca que a autocomunicação de massa se difere da mídia de massa tradicional, à medida que:

(...) o YouTube e outros sites com conteúdo gerado pelos usuários são meios de comunicação de massa. No entanto, eles se diferem da mídia de massa tradicional. Qualquer pessoa pode postar um vídeo no YouTube, com poucas restrições. E o usuário seleciona o vídeo ao qual deseja assistir e sobre qual comentar a partir de uma lista de possibilidades. (Castells, 2015, p. 115)

No jornalismo digital, por exemplo, o receptor também tem papel bastante ativo. Ele deixa de ser um mero leitor / espectador e passa a participar do processo de construção da notícia. Segundo Bertocchi (2016, p. 36), os receptores podem "escolher qual acontecimento merece ser transformado em notícia, podendo noticiá-lo, inclusive (...); têm o poder de escolher em que sítios buscar os dados que procuravam (...)". Muitas vezes, atuam como fontes, transmitindo informações aos jornalistas, que podem utilizá-las como pauta e, posteriormente, transformá-las em notícia.

Outro fator importante no que tange a autocomunicação de massa são as redes sociais, que podem se caracterizar como meio de representação virtual de atores sociais, normalmente de maneira individualizada, bem como suas respectivas conexões que se apropriam de um determinado site de rede social como suporte tecnológico. (RECUERO, 2009).

Os sites de redes sociais são ambientes públicos no ciberespaço, nos quais os indivíduos, por meio de perfis, são representados e compartilham com sua rede e contatos não somente informações e eventos de suas vidas de forma quase instantânea, mas notícias, curiosidades, opiniões. Como bem pontua Sibilia (2016), nesses sites “As últimas atualizações aparecem sempre 
no começo da página inicial e as mais antigas vão ficando cada vez mais abaixo, usualmente soterradas pela constante aluvião de novidades." (SIBILIA, 2016, p. 187)

Conforme aponta Recuero (2009), as redes sociais apresentam as seguintes características: Persistência: As informações postas permanecem no ciberespaço; Capacidade de busca: Possibilidade de que as informações e os atores sociais ali representados sejam localizados por instrumentos de busca, tanto da rede social, como, dependendo da configuração de privacidade, por mecanismos de buscas públicos como o Google; Replicabilidade: A possibilidade de que as publicações feitas no ambiente possam ser reproduzidas a qualquer momento; Audiências invisíveis: A impossibilidade de conhecer o público mediato alcançado pela informação disposta pelo usuário através de seus perfis em redes sociais.

Três destas características merecem especial atenção com relação ao que denominamos direitos da personalidade, em especial o direito à privacidade e ao direito ao esquecimento: a persistência, a replicabilidade e as audiências invisíveis. Abordaremos essas questões sob o prisma legal mais adiante. No que concerne ao controle judicial, é importante destacar a capacidade de essas informações estarem vinculadas aos mecanismos de busca públicos, tais como os populares google e yahoo.

Muito embora os primórdios da internet tivessem um viés de propagação de informação das mais diversas, a popularização do que chamamos de redes sociais, como os sites Instagram, Twitter e Facebook, demonstraram uma outra face da internet, na qual há a supervalorização do indivíduo, destacando-o como ator principal e objeto de sua própria comunicação.

Ademais, pode-se acrescentar ainda que o que caracteriza o século XXI é a sociedade de informação. O termo surgiu na década de 1970, criado por Daniel Bell (1919-2011) a fim de definir a sociedade pós-industrial e a difusão de informação nesse meio. Distanciando de uma sociedade do conhecimento, a sociedade de informação tem como bases o armazenamento e a disseminação da informação através dos mais diversos suportes. Bases de dados bastante aprimoradas guardam infinito número de informações, às quais o receptor chega por meio de mecanismos de busca, tais como Google e Yahoo.

Cabe ressaltar que os mecanismos de buscas, nos dias de hoje, são cada vez mais sofisticados. E tais mecanismos não seriam possíveis sem as bases de dados, que se sofisticaram com o desenvolvimento da internet. Segundo Suzana Barbosa (2007, p. 22): 
Atualmente, muitos estudos - circunscritos tanto na área das novas mídias, da cibercultura, da comunicação, do jornalismo, das artes, das ciências da computação, da inteligência artificial, da economia - têm delineado perspectivas e apontado funções para as bases de dados que descortinam as novas linhas de força, os modos de operação, de representação, as potencialidades que as atravessam e as colocam num patamar diferenciado.

A web oferece um grande potencial de visibilidade e de exposição, o que pode ser tanto uma qualidade marcante quanto um problema dependendo de como seja utilizado pelos usuários e pelas características específicas de cada rede social, assim como pelas configurações de privacidade ${ }^{6}$.

O refinamento das buscas e a grande capacidade de armazenamento de informações implicam uma espécie de vida virtual permanente, que se torna praticamente impossível de ser delimitada e completamente eliminada, caso o usuário se arrependa do conteúdo postado. Mesmo que o usuário exclua a publicação, é possível a tela já tenha sido capturada, ou realizado o download da imagem ou vídeo, apenas para citar alguns exemplos. Em outras palavras, a exclusão do conteúdo do perfil do usuário não impossibilita que aquele conteúdo, mesmo que publicado por poucos segundos, já não tenha sido "registrado" ou "copiado".

Assim, a permanência das informações postas em redes sociais e vinculadas aos buscadores pode dificultar ou até mesmo impossibilitar apagamento de dados que podem, em alguns casos, ter reflexos negativos, e, em situações mais graves, ferir a honra e moral dos usuários, em especial quando configuram crimes de injúria, calúnia ou difamação; tornando mais difícil a exclusão quando as postagens partem de outros usuários de forma difusa.

Além disso, os caráteres de replicabilidade e audiências invisíveis das redes sociais fazem com que os usuários possam "perder o controle" das informações, gerando o que especialistas chamam de digital footprint, isto é, rastros digitais que podem macular a imagem do usuário, tanto na rede social, quanto fora dela, seja pela publicação de algo inerente a si ou na divulgação de alguma notícia ou fakenews. É necessário reconhecer, no entanto, que muitos usuários podem não ter este tipo de preocupação, desejar ter este "controle" ou ainda ter uma consciência mais plena das diversas dimensões que uma publicação na internet possa ter.

É possível afirmar que a internet se caracteriza pela perenidade. Tudo o que é publicado nos meios digitais, dificilmente, será excluído. Nesse sentido, no caso de notícias falsas ou qualquer tipo

\footnotetext{
${ }^{6}$ Dependendo da rede social, o usuário pode estabelecer configurações de privacidade, tanto para a exibição das postagens quanto dos usos dos dados de navegação.
} 
de publicação que propague inverdades, é fundamental que se discuta a questão do direito ao esquecimento digital.

\section{DIREITO AO ESQUECIMENTO DIGITAL}

Antes de adentrar no tema do direito ao esquecimento digital propriamente dito, é pertinente traçar algumas considerações acerca dos direitos da personalidade no ordenamento legal brasileiro.

Os direitos da personalidade ganharam projeção no mundo após a segunda Guerra Mundial com o advento da Declaração Universal dos Direitos Humanos em 1948 (SCHEREIBER, 2014), sendo considerados inerentes à pessoa humana. Tais direitos não foram propriamente contemplados pelas legislações civis nacionais anteriores ao Código Civil de 2002 (Lei n 10.406/2002). Portanto, pode-se remontar como sua concepção embrionária a positivação legal prevista na Constituição da República Federativa do Brasil de 1988.

Segundo Sarlet (apud FERMENTÃO \& SILVA, 2015), a dignidade da pessoa humana é a qualidade intrínseca e distintiva do indivíduo que o faz merecedor de respeito perante a sociedade e o Estado. A dignidade humana fundamenta os direitos da personalidade, sendo de base jusnaturalista, precede o próprio Estado. Deste modo, segundo Schreiber (2014, p. 8) a dignidade da pessoa humana

(...) não corresponde, portanto, a algum aspecto específico da condição humana, mas exprime, isto sim, "uma qualidade tida como inerente a todo e qualquer ser humano", sendo frequentemente apresentada como "o valor próprio que identifica o ser humano como tal".

Muito embora haja divergência quanto ao fato de os direitos da personalidade e a dignidade da pessoa humana serem um conceito único, podemos entender os direitos da personalidade como decorrentes do princípio macro da dignidade da pessoa humana, visto que os direitos da personalidade se concentram majoritariamente na esfera individual.

É possível vislumbrar a positivação no Código Civil brasileiro de 2002 dos direitos da personalidade, descritos no artigo 11 do diploma legal citado como, além de intransmissíveis e irrenunciáveis, também impassíveis de limitação voluntária.

Ao tratar do direito ao esquecimento digital, cabe ressaltar os direitos da personalidade classificados no âmbito da integridade moral, os quais são mais afetados e relativizados na 
sociedade hiperespetacularizada propiciada pelas redes sociais e pela propagação permanente de informação por meio dos veículos do jornalismo digital.

Em 1960, Guy Debord (1997) já alertava para a questão da espetacularização da vida cotidiana. Segundo o autor, "o espetáculo não é um conjunto de imagens, mas uma relação social entre pessoas mediada por imagens" (p. 14). Com o surgimento da internet, esta relação social mediada por imagens tornou-se ainda mais forte, principalmente quando as redes sociais se configuraram como uma forma cada vez mais intensa de sociabilidade.

Certamente, um dos fatores que levou a discutir a questão dos direitos da personalidade no ambiente virtual foram as redes sociais e os jornais digitais. A característica da replicabilidade e permanência endossada por esses sites e os inúmeros usuários alcançados pelas publicações expuseram a questão da privacidade.

Desta forma, vislumbra-se a possibilidade de esfera moral do usuário ser atingida por publicações que de alguma forma possam prejudicar sua imagem perante a sociedade. Tal agressão é dificilmente totalmente reparada, à medida que a permanência própria das redes sociais permite que a informação prejudicial se mantenha disponível em rede.

Além disso, as chamadas fake news podem causar dano irremediável ao personagem da notícia, o que tem sido crescentemente empregado com fins políticos ou de geração de propaganda negativa para produtos, serviços, mas também para pessoas. No campo político, recentemente as fake News são tema de discussões na mídia e no judiciário sobre seus impactos em eleições e na estabilidade política. Frias Filho (2018) assevera que

O termo fake news deveria ser compreendido como toda informação que, sendo de modo comprovável falsa, seja capaz de prejudicar terceiros e tenha sido forjada e/ou posta em circulação por negligência ou má-fé, neste caso, com vistas ao lucro fácil ou à manipulação política. (FRIAS FILHO, 2018, p.43)

Uma vez publicada na rede, mesmo que haja algum tipo de retratação, a imagem do indivíduo pode ficar sujeita a descrédito ou manchada. É importante ressaltar que a utilização das redes sociais têm papel crucial no compartilhamento desse tipo de notícia. Segundo Cristina Tartáguila e Chico Marés (2018), em artigo escrito para revista Época, no período que antecedeu o primeiro turno das eleições presidenciais, no Brasil, em 2018, levantamento realizado pela agência Lupa de 
fact-checking revelou que as dez notícias falsas mais populares flagradas por checadores ${ }^{7}$ tiveram mais de 865 mil compartilhamentos no Facebook.

Uma delas diz respeito à atriz brasileira Patrícia Pillar e a seu ex-marido, o então candidato à presidência Ciro Gomes. Segundo uma notícia falsa - que, de acordo com o artigo de Tartáguila e Marés (2018), foi compartilhada mais de 35 mil vezes no Facebook -, ao longo do relacionamento, Patrícia teria sofrido agressões de Ciro. Por mais que o fato tenha sido negado pela atriz, o impacto da fake news, provavelmente, foi muito maior que o desmentido, depreciando a imagem do candidato. A notícia dificilmente será apagada da rede, o que pode associar Ciro Gomes à imagem de um agressor de mulheres.

The right to be forgotten, expressão traduzida no Brasil como direito ao esquecimento, no contexto do ciberespaço, foi criada em 2007 por Viktor Mayer-Schönberger, em função das reflexões acerca do direito à informação potencializadas pelas redes sociais e as possíveis agressões aos direitos da personalidade advindas dessa nova dinâmica. Ressalta-se que as postulações referentes ao direito ao esquecimento já eram discutidas antes do advento da internet e das redes sociais como hoje se estabeleceram, em especial na década de 1970, principalmente com relação a dados de condenações criminais já cumpridas.

O caso Lebach foi o primeiro episódio notório no qual foi possível perceber a utilização do direito ao esquecimento. O fato ocorreu na Alemanha, em 1969: três homens foram condenados pela morte de soldados, sendo dois a penas perpétuas e um a seis anos de reclusão. Este último, após o cumprimento da pena, foi posto em liberdade, porém a imprensa passou a divulgar matérias acerca do crime cometido há anos, tendo uma emissora produzido um documentário sobre o acontecimento, o que dificultava a ressocialização do ex-detento. Ao ser acionado, o Tribunal Constitucional Federal da Alemanha entendeu que a imprensa não poderia se beneficiar por tempo indeterminado com a explosão de um fato e que o direito personalíssimo agredido se sobreporia ao direito à informação, proibindo a veiculação do documentário. Ruaro e Machado $(2017$, p. 213) observam que:

(...) o direito ao esquecimento não fora mencionado de forma expressa no caso Lebach, mas que teve nele as bases para a sua discussão na medida que, no caso em comento, o Tribunal Constitucional Federal da Alemanha reconheceu a

\footnotetext{
${ }^{7}$ De acordo com o analista de sistemas Gilmar Lopes, em entrevista concedida a Fernanda Machado (2020), "a checagem de fatos não é uma atividade profissional nova, ela já existe desde 1994 com a Snopes, nos EUA. (...) Tradicionalmente o jornalismo trabalha em busca da notícia. O checador de fatos trabalha em cima de uma notícia que já está circulando".
} 
prevalência do direito fundamental à personalidade, especificamente a privacidade e intimidade - em detrimento do direito fundamental à liberdade de expressão.

Muito embora houvesse registro de caso semelhante julgado pela Corte Norte Americana na década de 1930 a respeito de uma prostituta acusada de homicídio e posteriormente inocentada, que conseguiu tutela jurisdicional para proibição da veiculação de um documentário contando sua história, o caso julgado pelo Tribunal Constitucional Federal da Alemanha serviu de marco ao direito ao esquecimento devido a sua grande repercussão.

No Brasil, o direito ao esquecimento ainda na esfera criminal foi observado no caso da Chacina da Candelária, através da veiculação de um programa da Rede Globo chamado Linha Direta que, ao dramatizar o ocorrido em 1993, quando oito moradores em situação de rua foram assassinados, expuseram imagem e nome de um dos indiciados como co-partícipe que fora absolvido da participação do crime em sentença final. Ao ter tal situação levada ao judiciário, foi indeferido o pleito na primeira e procedente na segunda instância. O fato foi apresentado através de recurso da Rede Globo ao STJ através do Recurso Especial (Resp) número 1134097-RJ, sendo julgado em 2013. De acordo com a sentença, a veiculação do programa foi proibida, e a TV Globo foi obrigada a pagar indenização por danos morais. Acerca desse julgado Ruaro e Machado (2017, p. 215), observam que “Em tal julgamento, entendeu-se, por unanimidade, que a proteção da personalidade do autor deveria preponderar sobre a liberdade de informação e de expressão".

Segundo o professor titular de direito civil da Universidade do Estado do Rio de Janeiro (UERJ) Anderson Schreiber (2017), o direito ao esquecimento no Brasil, mediante a concepção adotada pelo STF, apresenta três correntes que destacam posicionamento frente ao instituto, a saber: (1) Pró-informação; (2) Pró-esquecimento; (3) Intermediária.

A posição pró-informação é a mais defendida pelos sistemas de comunicação, que alegam que o direito ao esquecimento não possui previsão legal e não se relaciona com os direitos da personalidade, portanto não poderia se sobrepor ao direito à informação constitucionalmente previsto. Já a posição pró-esquecimento postula pelo direito ao esquecimento como instituto de expressão da dignidade da pessoa, resguardo ao seu direito de imagem e privacidade, afirmando que a exploração de fatos pretéritos constituiria uma pena perpétua, assim o direito ao esquecimento estaria acima do direito à informação. Por último, a corrente intermediária pondera que o direito ao esquecimento e o direito à informação estão no mesmo patamar constitucional, 
não havendo prevalência de uma sobre a outra. Dessa forma, apenas a análise do caso concreto seria capaz de demonstrar qual direito deverá prevalecer.

Para o presente artigo, optou-se pela corrente intermediária, visto que, em se tratando, não de fatos criminosos ou condenações penais, mas da rede mundial de computadores, nos parece uma posição mais adequada à medida que cada caso terá um impacto diferenciado.

Em sentindo amplo, o direito ao esquecimento "garante a dignidade da pessoa humana no sentido de resguardar a memória individual da pessoa, no que se refere a sua paz de espírito". (RIBEIRO, SANTOS \& SOUSA, 2018, p. 303). O direito ao esquecimento, antes evocado para que aqueles que cumpriram suas penas pudessem não ter indefinidamente as informações sobre os delitos cometidos veiculadas pela mídia, no século XXI, ganha um novo contorno, não se restringindo aos delitos noticiados por anos, mas também abarcando informações vexatórias e qualquer dado que possa ferir os direitos da personalidade, inseridos em base de dados na internet..

Com a entrada em vigor do Marco Civil da Internet no Brasil (L.12.965/2014), qualquer celeuma existente acerca dos dados que poderiam ser excluídos a pedido do usuário deveria comportar apenas os enquadrados como difamatórios ou caluniosos, visto que entendeu o legislador em seu artigo 70 uma concepção ampla, prevendo que:

Art. 7o 0 acesso à internet é essencial ao exercício da cidadania, e ao usuário são assegurados os seguintes direitos:

(...)

$X$ - Exclusão definitiva dos dados pessoais que tiver fornecido a determinada aplicação de internet, a seu requerimento, ao término da relação entre as partes, ressalvadas as hipóteses de guarda obrigatória de registros previstas nesta Lei;

(...) (BRASIL, 2014)

Nesse sentido, percebe-se que a exclusão dos dados pessoais - alcançando os direitos de privacidade, de imagens e todos os outros direitos da personalidade doutrinariamente entendidos como de integridade moral - pode ser requerida, ainda que as informações ali constantes sejam verdadeiras. Entretanto, mesmo que os dados sejam excluídos, seus rastros podem não ser apagados. Quando uma informação, em qualquer tipo de formato, é divulgada na internet, em função da velocidade do meio, algum usuário pode imediatamente salvá-la, tendo para si o registro e podendo, no futuro, inseri-lo na web novamente.

Vale destacar que o Marco Civil da Internet sofreu alterações em seu texto legal em 2018 através da nova redação da lei geral de proteção de dados pessoais - LGPDP (Lei no 13.709/2018). 
Embora ainda não vigente, a LGPDP que ganhará exigibilidade a partir de agosto de 2020, traz novos contornos ao tratamento de dados pessoais disponibilizados pelos usurários na internet, tanto em bancos de dados, como em redes sociais, facilitando o controle da disponibilização de dados e informações individuais, o que poderá a longo prazo, ainda que de forma oblíqua, ser utilizado em favor daqueles que evocam o direito ao esquecimento digital.

O termo Digital Footprint é utilizado a fim de denotar esses rastros virtuais deixados pelo usuário que, em alguns casos, podem macular ou não favorecer sua imagem dentro e fora do ambiente virtual. Ao não se restringir apenas a fatos caracterizados como calúnia ou difamação, o legislador adiciona como passível do direito ao esquecimento tais rastros digitais que, embora verdadeiros, não interessam ao usuário que se mantenham públicos:

Conceder a toda pessoa a autonomia sobre sua própria existência é um ato que the confere dignidade. Assim, dar ao indivíduo o direito a decidir sobre quais fatos pretéritos devem ser expostos novamente também é garantir o direito a participar ativamente sobre os rumos de sua vida, o que em última instância é conceder dignidade. (FERMENTÃO \& SILVA, p. 119, 2015)

Peter Fleisher (apud LIMA, 2013) divide o direito ao esquecimento digital, que enseja a postulação da exclusão dos dados disponibilizados, em três espécies, classificando-as conforme o usuário que divulgou a informação na internet, da seguinte forma:(1) O próprio usuário disponibiliza suas informações na internet;(2) O próprio usuário disponibilizou suas informações na internet e essas foram replicadas por terceiros; (3) As informações do usuário foram publicadas por terceiros.

Apesar de, em teoria, todas as hipóteses estarem agasalhadas sob o direito ao esquecimento, cabe salientar que a terceira espécie de divulgação pode encontrar atrito frente ao direito à informação, à liberdade de expressão, que são princípios constitucionalmente concebidos, em particular no que diz respeito às informações referentes a fatos de interesse público, notório, sobre governantes, funcionários públicos e celebridades. Como bem assevera Carlos Roberto Siqueira Castro, o direito à informação, que goza de status constitucional, previsto no artigo 5‥, XXXIII da Constituição brasileira, é "a mais fundamental das prerrogativas humanas, na medida em que o saber determina o entendimento e as opções da consciência, o que distingue os seres inteligentes de todas as demais espécies que exercitam o dom da vida". (CASTRO apud ROCHA, CUNHA \& OLIVEIRA, 2017, p. 490) 
$\mathrm{Na}$ perspectiva que encara o direito ao esquecimento como decorrente do direito à personalidade, reveste-se esse direito de um status constitucional, ficando no mesmo patamar legal do direito à liberdade de expressão e do direito à informação, explícitos na Constituição brasileira. Assim, a colisão entre o direito ao esquecimento e os direitos de liberdade de expressão e de informação, não poderiam compor nenhum tipo de hierarquia, não havendo prevalência de um sobre o outro e sim uma ponderação entre esses que deverá ser analisado caso a caso.

\section{O RECURSO ESPECIAL NO 1.660.168 - RJ: A PROMOTORA E O CONCURSO DA MAGISTRATURA DO} ESTADO DO RIO DE JANEIRO.

A fim de elucidar o direito ao esquecimento através de um caso concreto, tomemos como análise o recurso especial (Resp) número 1.660.168 - RJ, julgado em 2018. No presente caso, que tramitou em segredo de justiça, uma promotora do estado do Rio de Janeiro, ao prestar concurso para magistratura, realizado em 2006 no mesmo estado, foi acusada de fraudar o concurso, supostamente tendo o gabarito da prova de direito tributário. Ao analisar a denúncia de fraude, o Conselho Nacional de Justiça entendeu que não havia indícios suficientes para a configuração de fraude. Contudo, o fato de a promotora ser acusada de fraudar o certame foi amplamente divulgado por diversos veículos de comunicação, tanto em seus sites como em suas redes sociais, constando fotografia e nome da promotora.

Em 2009, a promotora ingressou com uma demanda judicial no Tribunal de Justiça do Rio de Janeiro (TJRJ) tendo como réus Google, Yahoo e Microsoft, visto que seu nome estava vinculado nos buscadores às matérias jornalísticas que a indicavam como fraudadora do concurso da magistratura.

A matéria foi apreciada pelo Supremo Tribunal de Justiça (STJ), tendo julgamento em 8 de maio de 2018. Em decisão final, o voto do Ministro Marco Aurélio Bellizze utilizou de maneira basilar o direito ao esquecimento a fim de conceder a tutela jurisdicional pleiteada pela promotora, qual seja, a retirada dos sites de busca das matérias que vinculam seu nome e imagem à fraude supostamente ocorrida no concurso da magistratura do Rio de Janeiro. Do voto do Ministro Bellizze, destacamos o seguinte trecho:

Assim, é imprescindível a atuação do Poder Judiciário, até para afastar a função de censor das ferramentas de busca em casos em que sustente a necessidade de interferência pontual para assegurar à pessoa em causa a quebra dessa vinculação 
eternizadas pelos sites de busca, a fim de desassociar os dados pessoais do resultado cuja a relevância se encontra superada pelo decurso do tempo. Essa é a essência do direito ao esquecimento: não se trata de efetivamente apagar o passado, mas de permitir que a pessoa envolvida siga sua vida com razoável anonimato, não sendo o fato desabonador corriqueiramente rememorado e perenizado por sistemas de busca. (STJ, Resp. 1.660.168/RJ)

Interessante destacar que o direito ao esquecimento, quando evocado para dados veiculados por jornais pela internet, indexado à buscadores, não tem o condão de apagamento absoluto das informações ali contidas, observada a permanência que as redes sociais evocam em seus conteúdos. Por outro lado, grande parte das informações são obtidas através de buscadores, o que coloca tais mecanismos como principais alvos dos julgados que visam a aplicação do direito ao esquecimento, como verificamos no caso analisado.

Nesse sentido, cabe citar Suzana Barbosa (2007, p. 47), que salienta que, atualmente, o que caracteriza as bases de dados disponíveis na internet - cada vez mais utilizadas não apenas como fonte de notícias, mas como pautas para matérias no chamado Jornalismo Digital em Base de Dados -, é a "sua possibilidade inerente de recuperação e filtragem do dado (ou dos registros nela inseridos) em múltiplas maneiras". De acordo com Barbosa (2007, p. 28), o Jornalismo Digital em Base de Dados é "um modelo que tem as bases de dados como definidoras da estrutura e da organização, além da apresentação dos conteúdos de natureza jornalística, de acordo com funcionalidades e categorias específicas, que vão permitir a criação, a manutenção, a atualização, a disponibilização e a circulação de produtos jornalísticos digitais dinâmicos".

No caso do jornalismo de dados, os dados são mais do que informações que ilustram uma notícia; eles são a própria razão da notícia. Assim, a análise de dados pesquisados em arquivos disponíveis na internet, por exemplo, pode se tornar uma notícia.

As bases de dados são fundamentais para o jornalismo atualmente e, ao utilizar essas informações como foco de notícias, tais elementos se tornam duplamente divulgados: pelas bases propriamente ditas e pelo veículo de comunicação.

É possível, então, afirmar que, como observado anteriormente, dificilmente um dado poderá ser totalmente excluído da internet. Assim, conforme aponta o jurista Luca Belli, o direito ao esquecimento digital é, na verdade, um direito à desindexação da informação à pessoa e não tem o condão de gerar o esquecimento por decisão judicial, ou seja: "a consequência da desindexação é que a informação pessoal desindexada deixaria de ser oferecida como resultado da busca sobre o 
nome da pessoa à qual se refere, mas continuaria sendo livremente accessível na Internet" (BELLI, 2018).

Como marco ao direito do esquecimento voltado ao ciberespaço, é possível citar o caso conhecido como Google Spain. Nesse caso, o espanhol Mario Costeja Gonzalez ingressou em 2010 junto à agência Española de Protección de Dados com uma demanda em face da empresa Google e o Jornal La Vanguarida, visto que no site de busca seu nome era indexado à matéria jornalística disponibilizada digitalmente no site do La Vanguarida referente à insolvência de Gonzalez e o arresto de seu imóvel ocorrido em 1988. Após discussões sobre a competência da agência Española de Protección de Dados e recursos impetrados pela Google Spain, o caso foi apresentado ao Tribunal de Justiça da União Europeia. Na decisão, a Corte enfrentou os temas referentes ao tratamento de dados disponíveis na internet, bem como o direito ao esquecimento, gerando precedente vinculante para os países da União Europeia. Conforme destacam Ruaro e Machado (2018, p. 211), nesse caso:

(...) o tribunal entendeu ser possível um juízo de proporcionalidade, a fim de conformar o interesse individual de proteção da privacidade e do direito ao esquecimento com o interesse público de acesso à informação, tendo em vista que nenhum direito é absoluto.

No Brasil, um exemplo de grande repercussão no que tange o direito ao esquecimento digital foi o caso Xuxa versus Google, no qual a apresentadora de TV, em 2010, requereu judicialmente no Tribunal de Justiça do Rio de Janeiro a desvinculação da frase "Xuxa pedófila" à divulgação de um vídeo seu com cenas sensuais extraídas do filme Amor, estranho amor, de 1982.

Diferentemente do exemplo analisado acima, o Rep. 1.316.921-RJ com relatoria da Ministra Nancy Andrighi, referente ao caso da apresentadora, apesar de ser considerado procedente em primeira instância, não obteve êxito no STJ, mantendo a vinculação de seu nome ao vídeo. Mesma sorte o caso obteve em reclamação de n. 15955 perante ao STF, em julgado de relatoria do Ministro Celso de Melo, que se deteve em analisar apenas processualmente a questão, mantendo a decisão proferida pelo STJ em 2017.

Tal caso demonstra que o direito ao esquecimento será analisado conforme a demanda específica, ponderando os interesses envolvidos, principalmente envolvendo pessoas públicas. Outrossim, insta salientar que, como a sociedade, o judiciário deve ser dinâmico, flexibilizando seus posicionamentos para adequar-se às demandas da sociedade, sempre observando a segurança 
jurídica. Portanto, poderá rever determinados posicionamentos conforme avançam as construções jurisprudenciais e doutrinárias sobre o tema.

No Supremo Tribunal Federal (STF) brasileiro, observa-se ainda a pendência do julgamento do Recurso Extraordinário 1010606, sob relatoria do Ministro Dias Tofolli, que irá decidir sobre a aplicabilidade do direito ao esquecimento na esfera civil quando for invocado pela própria vítima ou pelos seus familiares. Tal ação tem como interessados grandes mecanismos de busca na internet como Google e Yahoo, à medida que o presente recurso terá repercussão geral, ou seja, haverá vinculação desse julgado para as esferas inferiores.

\section{CONCLUSÃO}

O advento da cibercultura modificou no século XXI os suportes da sociedade de informação. No ambiente virtual, os conteúdos tornaram-se permanente e surgiram sofisticadas base de dados, que implicaram a indexação das informações e o refinamento dos buscadores. O que entra na rede dificilmente será apagado. Injusta ou justamente pessoas terão seus dados divulgados e, consequentemente, podem, em situações negativas, ter suas imagens maculadas, talvez, para sempre.

As mesmas características que podem oferecer a internet como um contexto complexo e poderoso de comunicação e interação podem ser motivadoras de problemas. Em muitos casos, a diferença dependerá das atividades, dos comportamentos e das atitudes dos usuários. Além disso, a exposição pode ser favorável em determinado momento, mas fonte de diversos problemas em outros. O nível de letramento digital do usuário e de sua inclusão digital crítica contribui para um uso mais pleno, consciente e estratégico dos sistemas e serviços on-line, dentre eles das redes sociais. O letramento digital pode, por exemplo, evitar que um usuário divulgue fake news ou que adote um comportamento de exposição demasiada.

O direito brasileiro vem se adaptando as novas dinâmicas sociais inseridas pelo advento da internet, modificando seu aparato para conferir a proteção necessária a direitos caros a um Estado Democrático de Direitos, tais como o direito a liberdade de expressão, liberdade de imprensa, direito a informação e direitos correlacionados a personalidade e dignidade da pessoa humana. Nesse cenário, além de temas sensíveis como Fake News, o judiciário brasileiro vê a necessidade de 
firmar posicionamento sobre outros, tais como o direito ao esquecimento, conforme desenvolvido no presente artigo, intrinsecamente relacionado aos direitos da personalidade.

Nesse contexto, há um atrito entre direitos igualmente relevantes e constitucionalmente garantidos em nosso ordenamento pátrio, quais sejam, o direito à informação e os direitos da personalidade. Frente a esse desafio, o judiciário brasileiro, a exemplo da jurisprudência europeia, vem adaptando o direito ao esquecimento ao meio digital.

Apesar da divergência doutrinária sobre o status legal gozado pelo direito ao esquecimento ser ou não equivalente à um direito constitucional, visto não estar expressamente previsto em nenhuma legislação brasileira, entendemos que o direito ao esquecimento visa a proteção não só dos direitos a personalidade, mas do princípio supralegal da dignidade da pessoa humana, desta forma não há que se falar em preponderância e sim de ponderação entre o direito ao esquecimento e os direitos a liberdade de expressão e o direito à informação, previstos expressamente na Constituição brasileira.

Os casos notórios enfrentados pelo judiciário brasileiro e o destaque da análise do caso referente ao Resp n. 1.660.168 - RJ demonstram que o judiciário brasileiro tende a se alinhar ao entendimento de ponderação, observando caso a caso qual princípio poderá prevalecer, adequando-se à necessidade premente de novas formas de proteção aos direitos da personalidade diante dos avanços proporcionados pela internet.

\section{REFERÊNCIAS}

BARBOSA, S. Jornalismo Digital em Base de Dados (JDBD): um paradigma para produtos jornalísticos digitais dinâmicos. 2007, 329 f. Tese (Doutorado) - Universidade Federal da Bahia, Faculdade de Comunicação, 2007.

DEBORD, Guy. A sociedade do espetáculo. Rio de Janeiro: Contraponto, 1997.

BAUMAN, Z. Modernidade líquida. Rio de Janeiro: Zahar, 2001.

BELLI, L. STJ consagra direito ao esquecimento na Internet: o que isso significa? Disponível em https://www.jota.info/coberturas-especiais/liberdade-de-expressao/stj-consagra-direito-aoesquecimento-na-internet-o-que-isso-significa-20052018 Acesso em 31/05/2019. 
BERTOCHI, D. Dos dados aos formatos: a construção de narrativas no jornalismo digital. Curitiba: Appris, 2016.

BRASIL. Constituição da República Federativa do Brasil DE 1988, Brasília, DF, out. 1988.

BRASIL. Lei no 10.406, de 10 de janeiro de 2002. Institui o Código Cívil, Brasília,DF, jan. 2002.

BRASIL. Lei no 12.965, de 23 de abril de 2014. Estabelece princípios, garantias, direitos e deveres para o uso da Internet no Brasil., Brasília,DF, abr., 2014.

BRASIL. Lei no 13.709, de 14 de agosto de 2018. Lei Geral de Proteção de Dados Pessoais (LGPD).

CASTELLS, M. A galáxia da Internet: reflexões sobre a Internet, os negócios e a sociedade. Rio de Janeiro, Zahar, 2003.

. O poder da comunicação. Rio de Janeiro, Paz e Terra, 2015.

FERMENTÃO, C. A. G. R; SILVA, T. M. B. O direito ao esquecimento como garantia da dignidade da pessoa humana na sociedade superinformacional: a quem pertence o passado? Revista Conped. Disponível em <http://www.conpedi.org.br/publicacoes/66fs/345/oy1ux21y/94NWsXt97fP0yDGE.pdf. Acesso em 22/05/2019.

FIGUEIREDO, F. V. Direitos da personalidade e o respeito à dignidade da pessoa humana. Disponível em https://fabiovieirafigueiredo.jusbrasil.com.br/artigos/112327969/direitos-da-personalidade-eo-respeito-a-dignidade-da-pessoa-humana Acesso em 16/05/2019.

FRIAS FILHO, O. O que é falso sobre Fake News. Revista USP, São Paulo, n. 116, p. 39-44, janeiro/fevereiro/março 2018

GOMES, O. Introdução ao Direito Civil. São Paulo: Gen editora, 2016.

LÉVY, P. Cibercultura. Tradução Carlos Irineu da Costa. São Paulo: Editora 34, 1999.

LIMA, E. N. K. P. Direito ao esquecimento. Discussão europeia e sua repercussão no Brasil. Disponível em http://www2.senado.leg.br/bdsf/bitstream/handle/id/502929/000991677.pdf Acesso em: $10 / 05 / 2019$ 
MACHADO, Fernanda. Checador de fake news só vê saída na educação. 3 maio 2020. Disponível em: https://digitais.net.br/2020/05/checador-de-fake-news-so-ve-saida-com-educacao/. Acesso em: $19 / 06 / 2020$

RECUERO, R. Redes Sociais na Internet, Difusão de Informação e Jornalismo: Elementos para discussão. Disponível em: http://www.raquelrecuero.com/artigos/artigoredesjornalismorecuero.pdf. Acesso em: $10 / 05 / 2019$

ROCHA, M. V. da; CUNHA, I. R.; OLIVEIRA, K. de F. R. Esquecimento, internet e "preferência" da informação: possibilidades de aplicação da doutrina dos preferred rights da jurisprudência norteamericana ao caso brasileiro. Revista Brasileira de Políticas Públicas, Brasília, v. 07, n. 3, p. 483-509, 2017.

RUARO, R. L. ; MACHADO, F. I. de S. Ensaio a propósito do direito ao esquecimento: limites, origem e pertinência no ordenamento jurídico brasileiro. Revista do Direito Público, Londrina, v. 12, n. 1, p.204-233, abr. 2017.

SANTAELLA, L. CULTURAS E ARTES DO PÓS-HUMANO: da cultura das mídias à cibercultura. São Paulo, Paulus, 2003.

SCHEREIBER, A. Direitos da personalidade. 2. ed. Rio de Janeiro: Atlas, 2014.

. As três correntes do direito ao esquecimento. As posições que foram delineadas na audiência pública realizada pelo STF. Disponível em https://www.jota.info/opiniao-eanalise/artigos/as-tres-correntes-do-direito-ao-esquecimento-18062017 Acesso em 31/05/2019.

SIBILIA, P. O show do Eu: A intimidade como espetáculo. Rio de Janeiro, Contraponto, 2016.

STJ. Recurso Especial: REsp 1.660.168 RJ 2014/0291777-1. Relator: Ministro Marco Aurélio Bellizze. DJ: 05/06/2018. Disponível em: <https://stj.jusbrasil.com.br/jurisprudencia/595923405/recursoespecial-resp-1660168-rj-2014-0291777-1/inteiro-teor-595923409?ref=juris-tabs >. Acesso em: $31 / 05 / 2019$. 
STJ. Recurso Especial: REsp 1316921 RJ 2011/0307909-6. Relator: Ministra Nancy Andrighi. DJ: 29/06/2012. Disponível em: <https://stj.jusbrasil.com.br/jurisprudencia/22026857/recursoespecial-resp-1316921-rj-2011-0307909-6-stj/inteiro-teor-22026859 >. Acesso em: 31/05/2019.

STJ. Recurso Extraordinário: RE 1010606. Relator: Ministro Dias Toffoli. Disponível em: < http://www.stf.jus.br/portal/jurisprudenciaRepercussao/verAndamentoProcesso.asp?incidente=5 091603\&numeroProcesso=1010606\&classeProcesso=RE\&numeroTema=786>. Acesso em: $31 / 05 / 2019$.

TARTÁGUILA, C.; MARÉS, C. Dez notícias falsas com 865 mil compartilhamentos: o lixo digital do 1o turno. Revista Época, 7 ago, 2018. Disponível em: <https://epoca.globo.com/cristinatardaguila/dez-noticias-falsas-com-865-mil-compartilhamentos-lixo-digital-do-1-turno-23129808>. Acesso em: 19/06/2019. 
Recebido em 25/05/2020

Aceito em 18/06/2020

(c)(1)(0)

BY NC SA 